\title{
Review
}

Source: The Musical Times and Singing Class Circular, Vol. 14, No. 328 (Jun. 1, 1870), pp. 503-504

Published by: Musical Times Publications Ltd.

Stable URL: http://www.jstor.org/stable/3353400

Accessed: 06-06-2016 18:14 UTC

Your use of the JSTOR archive indicates your acceptance of the Terms \& Conditions of Use, available at

http://about.jstor.org/terms

JSTOR is a not-for-profit service that helps scholars, researchers, and students discover, use, and build upon a wide range of content in a trusted digital archive. We use information technology and tools to increase productivity and facilitate new forms of scholarship. For more information about JSTOR, please contact support@jstor.org.

Musical Times Publications Ltd. is collaborating with JSTOR to digitize, preserve and extend access to The Musical Times and Singing Class Circular 
placid theme, deeply sympathetic with the words, breathes throughout that pure and fervent expression of faith so observable in all the choral music of its author. Some few passages of imitation are introduced ; but the general design of the composition-an outpouring of hopeful resignation-is never sacrificed for the exhibition of scientific knowledge, a merit which cannot be too much taken to heart by many who aspire to become recognised composers of sacred music. No. 2 is rather more vivacious in character, as the subject demands, and is written with a masterly hand for the voices throughout The treatment of the words, "()ur God saith : I will exalt them," is excessively beautiful, the repetition of the phrase in the different parts having an excellent effect. With any choir where reliance can be placed upon the male voices alone, there can be little doubt that these choruses will become favourite pieces: and, in addition to their intrinsic merit, they will now have the charm of novelty, for we believe that they have never yet been heard in England. We cannot conclude our notice without a word of commendation to Madame Natalia Macfarren, who has adapted the words with much skill and intelligence.

Saw ye not the pallid Angel? Motett for four voices. Composed by F. MTendelssohn Bartholdy.

Trere is a heavenly glow of beauty about this Motett which must make itself felt by all hearers. The opening subject, in G minor, is exquisitely melodious, and flows on so sympathetically with the words, adapted by Madame Macfarren. that they seem to have been originally allied with the composer's music. There are so many lovely points in this composition that we scarcely can hope to speak even of one half of those which strike us. Let us, however, especially mention the seraphic phrase to the words, "Whom, O angel, do thy white wings beckon?", the calm close upon the dominant harmony in the minor key, which so appropriately concludes the sentence "He is no more," and the sudden awakening into the full brightness of the major key, to the joyful words "Smiling does he sleep." The final phrase too, in which these words are repeated, as if with a lingering love which cannot be withdrawn, is too tender and deeply pathetic to admit of more than a faint indication of its effect upon the listener. Choral Societies should at once become acquainted with such a newly found treasure as this, for there can be no question of its cordial welcome even with the most apathetic audience.

Original Tunes to popular Hymns, for use in Church and Home. By Joseph Barnby.

THIs collection of those excellent Hymn Tunes which Mr. Barnby has contributed to various works at different times, will be found both useful and interesting. His few remarks in the preface show that he has not composed them at hap-hazard, but that, like a real artist, he has pictured to himself a clearly defined ideal, and striven to reach it regardless of praise or blarae. What we all desire to have in our Hymn Tunes is, sweetness of melody, purity of harmony, and originality of cadence; assuming, of course, that the compass of the parts is judiciously limited. In nine-tenths of the tunes now fashionable, weakness of melody takes the place of sweetness, tameness of harmony passes current for purity, and as to freshness of cadence, the value of it seems unknown. Not so in the collection before us. Judged by the highest standard, it will be found full of gems. For beauty of melody, few tunes can surpass " Holy, Holy, Holy" (p. 7), "When shades of night" (p. 17), "O come, all ye faithful" (p. 26), "Twas in the winter cold" (p. 38), "Sleep thy last sleep" (p. 42), and "() day of rest and gladness" (p. 50). As a specimen of the elegant manner in which phrases can be welded together, "Come gracious Spirit, heavenly Dove" (p. 16). deserves special notice; the only perfect cadence in it being at the final close ; on this account the melody floats smoothly on and on to the end. "Hark, hark, my soul " (p. 70), will be a great favourite for similar reasons. "Lead, kindly light" (p.44), is of a good bold type, and will certainly displace many better known tunes to the same words. The only fault that can be found with the collection as a whole is, perhaps, the too frequent use of the modulation into the relative minor of the dominant. One or two tunes also are somewhat enervated by a too liberal indulgence in dominant discords. The elegant falling of the leadingnote in melodic phrases, which suggests Gounod so strongly, we gladly welcome; when handled skilfully the effect is always beautiful. Whilst giving the music the praise it deserves, we must not overlook the excellence of the type, and the chaste taste displayed in the binding of this work, which will indeed be welcomed by Home and Church.

\section{Original Compositions for the Organ.}

By Frederic Archer.

No. 1, Andante in D. 2, Andante in $F .3$, Andante in $A$.

Mr. Archer is the more successful in these movements because he has not been ambitious. In all of them the interest is supported well throughout, the phrasing is marked and good, and as might be expected from him, the passages lie well under the hands. No. 1, in D, opens with graceful melody in the upper part, the left hand sustaining the harmony, whilst the pedal part marks the rhythm by a staccato accompaniment. This theme leads into a flowing passage for the manuals alone, in the subdominant; after which, a reintroduction of the first theme closes the movement. No. 2 , in F, is of a more classical stamp than No. 1 , but is very similar to it in form. Botri of the above are good and will make most effective voluntaries; but No. 3, in A, certainly surpasses them both, in breadth of design, originality of melody, and freshness of modulation, though, perhaps, putting the performer's powers to a greater test, as it will by no means bear an unsympathetic rendering. Altogether these Andantes are a most promising instalment of a class of pieces much required by organists.

\section{Wayside Sketches for the Pianoforte. Waving Ferns.} By Arthur U'Leary.

WE presume this to be one of a series of small pieces for the pianoforte, although the name of no other appears advertised, and this one is not numbered. A group of sketches as elegant as " Waring Ferns" would be acceptable to teachers who desire that their pupils should cultivate the mind as well as the fingers. There is little pretension in the composition, but it may safely be recommended as the production of a refined and thoughtful musician, who is gradually working his way to a position of importance.

Easy Duets for the Pianoforte. Arranged expressly for young beginners.

\section{By Robert Fieldwick.}

A GOoD word must be said for these duets, for not only are they so carefully arranged as to lie easily for the hand of a child, but the airs are exceedingly well selected. A French air, a waltz by Beethoven, a portion of Haydn's Military Symphony, the "Florence Waltz" by Mr. Fieldwick, and the Minuet from Don Giovanni, are contained in the book. and firm a sufficiently varied selection to please the most exacting little performer.

\section{An Evening on the Sea. Reverie, for the Pianoforte.} Composed by Gustav Wolff.

A Flowing and graceful subject in 8 rhythm, accompanied throughout in triplets, the undulating effect of which has been accepted as the musical representation of waves for such a length of time as to place the matter beyond a doubt. The general design of the piece is, we presume, an attempt to depict the calmness of feeling induced by a cloudless evening at sea, with only a gentle ripple-for the episode in the relative minor is scarcely ripple-for the episode in the relative minor is scarcely
sufficiently agitated to inconvenience the veriest landsman 
-and we may say, that on the whole, this idea is well carried out. A good effect is gained where, on the return to the original key, the theme is given to the left hand.

The Gipsies. A Cantata. Words by Marmaduke E. Browne. Music by Edwin Aspa.

THrs bright little composition comes to us in pianoforte score, adapted of course for drawing room performance; but although we are inclined to look favourably upon it in this shape, there can be no question that it wants the colouring of the instrumentation to give it due effect, the work being so exceedingly simple and unpretentious in design as to be occasionally somewhat feeble with the mere pianoforte accompaniment, more especially in the choral parts. The composer has evidently much feeling for that important element in a Cantata obviously written to catch the public ear, which we should perhaps rather call " tune" than "melody;" and throughout his composition he has so liberally used this power, that we have little doubt of future representations of the work being as successful as we are apprised that the first performance of it was, a short time back, at a concert given by the South Warwickshire Harmonic Society, at Leamington. The opening chorus is based upon a pretty subject which cannot fail to please, and includes an effective modulation at the words "Merry, merry are we," the whole piece well expressing the popular notion of the light and joyful character of Gipsy life. The duet which follows, opens with a graceful melody for the soprano, succeeded by an extremely vocal theme for the tenor; and where the voices are afterwards united, we have some better writing than is to be found in any other part of the Cantata. The mezzo soprano solo, "When stars are bright," and the unaccompanied quartett are, perhaps, scarcely as good as the following bass song, "What cares the Gipsy," which commences with a bold subject, in D minor, full of character, and excellently adapted to the words. The concluding quartett has a theme, in waltz measure, the latter portion of the opening chorus being repeated to conclude the composition. On the whole, we consider that the Cantata, although laying no claim to much depth of thought, successfully fulfils its composer's object ; and its light and cheerful character will unquestionably secure for it a favourable reception with many Choral Societies.

\section{Chappelil and Co. \\ Ireland. Grand Fantasia on Irish Melodies. By Brinley Richards.}

As this Fantasia is dedicated to Madame Arabella Goddard, it may be expected that the majority of amateur will have some considerable amount of hard work before them if they desire to give due effect to the piece. The "Last Rose of Summer" and "St. Patrick's day," are the melodies chosen by Mr. Richards; and we need scarcely say that the embellishments are refined and graceful throughout. There is much variety in the treatment of the airs; and some effective changes of key prevent any undue monotony in the variations.

By the way of the Sea. Ballad. Words by the Earl Cathcart. Music by R. Sloman, Mus. Doc., Oxon.

Dr. Sloman has written a graceful and musicianlike ballad, sufficiently simple to ensure favour with vocalists who are more ambitious to display expression than execution. We are not sure whether the mournful phrase at the end will not rather mar the effect of the song in performance; but the words inexorably demand such music.

\section{A. Dimoline, Bristol.}

The Angels' Song (Der Engel Gesang). By Goethe. Composed by E. G. Whately.

There is merit in this sacred song; but the composer does not quite know what to do with his materials, and the consequence is that it is too fragmentary in character to be accepted as a musicianlike setting of the words
Frequent changes of key will not compensate for want of creative power, nor will rapid arpeggios conceal the poverty of a melody. The modulation which flows on most agreeably is that on the fourth page; and the return to the original key is also well effected. We must protest, however, in the interest of purity of writing, against the triad of $\mathrm{G}$ sharp leaping down to the 6 on $\mathrm{C}$, which so often occurs as to lead us to imagine that Mr. Whately likes it; and also to the $G$ in the accompaniment for the left hand, at the end of the 7 th bar ; this should assuredly be $\mathrm{E}$.

\section{Ashdown and Parry.}

The Streamlet. Sketch for the Pianoforte. By T. Albion Alderson.

The recollection of Mendelssohn's graceful little piece, illustrative of the same idea as that selected by Mr. Alderson, will not interfere with the success of this sketch ; for, although to a certain extent all pianoforte "Streamlets" must resemble each otner, the one before us is neither a copy nor a paraphrase of its predecessor. The melodious subject in the left hand flows calmly on against the triplets in the upper part; and the composer may be congratulated on resisting the excessive modulations which are so continually seized upon to give " character" to a piece, which would often have none without them. This little composition may be fairly recommended to those who do not select music merely on account of its difficulty.

\section{Lamborn Cock and Co.}

Golden Dreams. Song. Words by E. C. D. Music by Francesco Berger.

A well.written song, evidently the production of a skilled musician and a thoughtful composer. We should have preferred it, however, if the harmonies had been laid on with a more sparing hand: the chromatic chords interfere with the boldness of the melody in sume places -as, for instance, where the $\mathrm{F}$ is sharpened, in the first bar of the third line, page 3, upon the dominant harmony of E flat (the D in which, by the way, should evidently be marked natural)-but a good contralto singer and a good accompanist may unite their powers with much effect in this composition.

What we have loved, we love for ever. Song. Words from "The Afterglow." Music by Ciro Pinsuti.

Sigxor Pinsuti always writes in that charmingly melodious and unaffected style which many more ambitious but less talented composers would do well to imitate. The song before us is, in every respect, one of the most fascinating trifles we have lately seen from the pen of this composer.

The Bird at Sea. Song. Written by Mrs. Hemans. Composed by Daniel Middleton.

Mrs. Hemans's pretty words have been wedded to an appropriately simple melody by Mr. Middleton; and the result is a song with which unassuming young vocalists may please both themselves and their listeners. We think it would have been better if the composer had written his chord of the dominant seventh in the accompaniment lower down, where the $F$ is chromatically raised in the voice part, but generally the harmonies are carefully considered; and a happy use of what is technically called the " augmented triad " deserves mention.

The Syren. Song. Poetry by Robert Buchanan (from “Undertones"). Music by Francesco Berger.

There is so much character in this composition as to make it stand apart from the conventional songs of the day. The opening is extremely graceful, the voice having a melodious theme, accompanied with a light arpeggio in the right hand, and a monotonous legato bass. The excessive variety obtained by the most legitimate means, after the first double bar, deserves the warmest commendation, the change into G major, with the placid accompaniment, contrasting excellently with the phrase to the 